\title{
Editorial
}

\section{Changing mental health legislation in the $\mathrm{UK}^{+}$}

\author{
Tony Zigmond
}

Abstract Following devolution, the mental health acts of the constituent countries of the UK are diverging in their provisions. This editorial describes three significant differences between the new Mental Health (Care and Treatment) (Scotland) Act 2003, which came into effect in Scotland in 2005, and the Mental Health Act 2007 for England and Wales.

Devolution, in relation to mental health law, has come of age. The Mental Health (Care and Treatment) (Scotland) Act 2003 is very different both from its forerunner in Scotland and from the Mental Health Act 1983 for England and Wales, even as amended by the Mental Health Act 2007. Should the report of the Bamford Review of the legislative framework in Northern Ireland (Bamford Review of Mental Health and Learning Disability (NI), 2007) be accepted and turned into a mental health act then we will have a third, very distinct, piece of mental health law within the UK.

There are three fundamental differences between the new mental health acts for Scotland and for England and Wales.

\section{Incapacity}

First is the criterion of significantly impaired decision-making, required before a person can be made subject to compulsion under the Scottish Act. This caused considerable debate both in Parliament and in the Royal College of Psychiatrists in relation to the provisions for England and Wales. Those in favour argued that mental health law should mirror, as closely as possible, the legal provisions for people with physical illnesses. As was said by Dame Elizabeth Butler-Sloss in the case of Ms B (B v. An NHS Hospital Trust [2002]),

\footnotetext{
'a competent patient has an absolute right to refuse to consent to medical treatment for any reason, rational or irrational, or for no reason at all, even when that decision may lead to his or her death'.
}

It has been argued that we should not have any separate mental health legislation and that the mental capacity legislation, with perhaps some additional safeguards, should be the basis for all non-consensual treatment (Zigmond, 1998; Szmukler \& Holloway, 1998). The proposals for Northern Ireland are in line with this approach. The College in England and Wales took the view, as had already been accepted in Scotland, that the criteria for determining capacity as set out in the Mental Capacity Act 2005 are too narrow for use with people with a mental disorder, being based largely, albeit not exclusively, on cognitive ability. It was argued that although a person who retains full decisionmaking ability should keep their personal autonomy, in order not to exclude from compulsion people with disorders of mood or abnormal thinking, the concept of significantly impaired decision-making by reason of mental disorder is a more appropriate test as a criterion for non-consensual treatment.

It was recognised, however, that any criterion pertaining to mental capacity may cause difficulty in relation to mentally disordered offenders. If a court determined that a mentally disordered person must be locked up then that person would not have the option of choosing voluntary admission to hospital. There would be a danger, if the impaired decisionmaking criterion applied to those who would be detained under Part 3 of the Mental Health Act 1983, that people who retained decision-making ability

${ }^{+}$See pp. 89-97, this issue.

Tony Zigmond is a consultant psychiatrist with Leeds Partnerships Foundation Trust (Newsam Centre, York Road, Leeds LS14 6WB, UK. Email: anthony.zigmond@leedspft.nhs.uk). A former Vice-President of the Royal College of Psychiatrists, he was the College lead on mental health law reform. 
would have to go to prison even if they might benefit from admission to hospital. Hence the College's position that this criterion, significantly impaired decision-making, should apply only in relation to Part 2 detentions.

Those who argued against the impaired decisionmaking criterion did so on the basis that the appropriateness of compulsion should be determined solely on the basis of risk. If there is risk to the health or safety of the person or of other people then detention under the Mental Health Act should be an available option even if the person retains full decision-making ability. This was the position of the government in England and Wales but not the government in Scotland. The result is that people with mental disorders who retain full decisionmaking ability may be detained under a civil section in England and Wales but not in Scotland.

\section{Advance directives}

The issue of impaired decision-making as a criterion also raises the interesting question of the status of advance directives. An advance directive is the capacitous refusal of treatment moved forward to a time when the intervention would be medically appropriate but the patient has lost decision-making capacity. In relation to mental capacity legislation, an advance refusal is as valid as if it is made at the time the decision is required. Advance directives have no validity in relation to detention and treatment under the Mental Health Act in England and Wales because capacitous refusal of treatment can be overridden. (The Mental Health Act 2007 amends this in relation to electroconvulsive therapy (ECT). A patient cannot be given ECT in the face of capacitous refusal, other than in an emergency (under section 62(a) or (b)). This also applies to advance directives refusing ECT.) It might have been argued that, given that a person who retains full decision-making ability cannot be detained in Scotland, an advance directive refusing detention, made by a fully capacitous person with a full understanding of the relevant circumstances, should be applicable and honoured. This was presumably a step too far. Account has to be taken of advance directives, as in England and Wales, but they can be overruled by the Scottish Act.

\section{Compulsion exceeding 28 days}

Second, the Scots have adopted a proposal that was in both the 2002 and 2004 draft mental health bills for England and Wales but abandoned when the government decided to amend the Mental Health Act 1983. That is, that all compulsion after 28 days, be it detention in hospital or compulsory treatment in the community, must be authorised by a mental health tribunal. This exceeds the requirements of Article 5 of the European Convention on Human Rights which, perhaps oddly, states that although anyone detained on the grounds of committing an offence must have an independent 'hearing' by a court, detained patients have a right to a 'hearing' only if they request one (so patients who are too ill or intellectually disabled to request an appeal, arguably the most vulnerable, do not have one for at least 6 months). Lyons (2008, this issue) suggests that the Scots may be having some difficulties with the resource requirements of this provision (which was the reason the proposal was not pursued in England and Wales).

\section{Roles and responsibilities}

The third major difference is that in Scotland the roles and responsibilities of different professional groups are largely unaltered. The Mental Health Act 2007, for England and Wales, enables clinical psychologists, mental health nurses, occupational therapists and social workers to take on the responsibilities of being in overall charge of patients' care and treatment. Particularly controversially, it also permits professionals who are not registered medical practitioners to provide the medical report required to renew detention orders. The European Court on Human Rights (Winterwerp v. Netherlands [1979]) stated that 'objective medical expertise' is required to determine whether the patient has a mental disorder of a nature or degree to warrant detention. There is a question as to whether or not this can lawfully be provided by non-medical professionals. Parliament's Joint Committee on Human Rights, in its fourth report, stated,

'In Varbanov v Bulgaria the Strasbourg Court gave every indication ... that objective medical expertise involved reports from psychiatrists who are doctors. The Court made it clear that the opinion of a medical expert who is a psychiatrist is necessary for a lawful detention on grounds of unsoundness of mind' (Joint Committee on Human Rights, 2007a: p. 12).

\section{It continued,}

'in some circumstances it might be appropriate for a clinical psychologist to provide the tribunal with the objective medical expertise [for renewal of detention]' (p. 14).

The government rejected this view. In its 15 th report the Joint Committee stated:

'In the Government's view the term "medical expertise" in Winterwerp was "used in the wider sense and the court was not seeking to lay down which sort of qualifications available in a national system would 
be acceptable and which would not." We hold to the view that the term medical expertise has a minimum content, and that the current case law suggests that this requires that the person be medically qualified' (Joint Committee on Human Rights, 2007b: p. 6; bold as in original).

How many non-medical professionals will wish to take up these roles and responsibilities is not known. Whether it is lawful will, no doubt, be decided by the courts.

\section{Which country has the 'better' Act?}

The scope for research, given the divergent pathways of different parts of the UK, is considerable. Whether one set of provisions turns out to be more effective, however this is to be measured, than another or whether they will be seen to be just different only time will tell. The Scots do, however, have one significant advantage. The principles behind the Scottish Act have met with universal approval from all stakeholders. The recently amended mental health act for England and Wales will need to demonstrate that it is ethical, workable and effective if it is to win over the hearts and minds of many of those who have to operate it, or will be subject to its provisions.

\section{Declaration of interest}

T. Z. represented the Royal College of Psychiatrists throughout the Mental Health Bill's passage through Parliament.

\section{References}

Bamford Review of Mental Health and Learning Disability (NI) (2007) The Bamford Review of Mental Health and Learning Disability (Northern Ireland): A Comprehensive Legislative Framework. Consulation Report. TSO (The Stationery Office) (http://www.rmhldni.gov.uk/index/published-reports/clframework.htm).

House of Lords House of Commons Joint Committee on Human Rights (2007a) Legislative Scrutiny: Mental Health Bill. Fourth Report of Session 2006-07. TSO (The Stationery Office) (http:/ / www.publications.parliament.uk/pa/jt200607/jtselect/ jtrights $/ 40 / 40$.pdf).

House of Lords House of Commons Joint Committee on Human Rights (2007b) Legislative Scrutiny: Seventh Progress Report. Fifteenth Report of Session 2006-07. TSO (The Stationery Office) (http:/ / www.publications.parliament.uk/pa/jt200607/ jtselect/jtrights/112/112.pdf).

Lyons, D. (2008) New mental health legislation in Scotland. Advances in Psychiatric Treatment, 14, 89-97.

Szmukler, G. \& Holloway, F. (1998) Mental health legislation is now a harmful anachronism. Psychiatric Bulletin, 22, 662-665

Zigmond, A.S. (1998) Medical incapacity act. Psychiatric Bulletin, $22,657-658$

B v. An NHS Hospital Trust; B (Adult: refusal of medical treatment) [2002] EWHC 429, [2002] All ER 499.

Winterwerp v. Netherlands [1979] 2 EHRR 387. 